\title{
Expression of erythroblastic leukemia viral oncogene homolog (erbBS) mRNAs and possible splice variants in 3T3-L1 preadipocytes
}

\author{
ELEONORA PAGANO $^{1,2,4}$, VANINA FONTANA ${ }^{3}$ and JUAN CARLOS CALVO ${ }^{1,3}$ \\ ${ }^{1}$ Laboratorio de Química de Proteoglicanos y Matriz Extracelular, IByME; ${ }^{2}$ Laboratorio de Biología Celular y Molecular, \\ PIB-UCA-CONICET; ${ }^{3}$ Departamento de Química Biológica, Facultad de Ciencias Exactas y Naturales, \\ Universidad de Buenos Aires, Ciudad Universitaria, Buenos Aires, Argentina
}

Received February 3, 2011; Accepted June 3, 2011

DOI: $10.3892 / \mathrm{mmr} .2011 .517$

\begin{abstract}
Previously, we studied the erythroblastic leukemia viral oncogene homolog (erbB) family of tyrosine kinase growth factor receptors in terms of protein expression, modulation and activation in the 3T3-L1 cell line. In the present study, the presence of full-length erbB mRNAs, and splice or proteolytic erbB variants, was evaluated using RT-PCR. Epidermal growth factor receptor (EGFR)/erbB1 expression was confirmed. Wild-type (wt) ErbB2, human erbB2 (HER2)extracellular domain (ECD) and herstatin mRNA expression were analyzed. Restriction analysis confirmed wt expression. 3T3-L1 cells exhibited HER2-ECD and herstatin mRNA expression, although at extremely low levels (compared to the control cell lines). ErbB3 cDNA was amplified using mouse mammary tumors and rat acines as positive controls. ErbB4 was not positively identified in these cells. In conclusion, this study demonstrates that 3T3-L1 cells express EGFR/erbB1, erbB2 and erbB3, and possibly, certain erbB2 splice or proteolytic variants, which are worth pursuing.
\end{abstract}

\section{Introduction}

The erythroblastic leukemia viral oncogene homolog (erbB) family of tyrosine kinase growth factor receptors consists of

Correspondence to: Dr Eleonora Pagano, Laboratorio de Biología Celular y Molecular, Programa de Investigaciones Biomédicas, Pontificia Universidad Católica Argentina (PIB-UCA-CONICET), Alicia Moreau de Justo 1600, $3^{\circ}$ Piso (C1107AFF), Buenos Aires, Argentina

E-mail: eleonora_pagano@yahoo.com.ar

Present address: ${ }^{4}$ Dr Eleonora Pagano, Facultad de Ciencias Médicas, Pontificia Universidad Católica Argentina, Alicia Moreau de Justo 1500, $4^{\circ}$ Piso (C1107AFF), Buenos Aires, Argentina

Key words: erythroblastic leukemia viral oncogene homolog (erbB) 1/ epidermal growth factor receptor, erbB2, erbB3, erbB4, 3T3-L1 cells, preadipocytes, heregulin isoform 2-extracellular domain, herstatin transmembrane proteins that dimerize in order to transduce their signal. This homolog includes the epidermal growth factor receptors (EGFRs) erbB1, erbB2, erbB3 and erbB4. These receptors share a similar structure and a high degree of homology (1) i.e. a glycosylated extracellular binding domain, a single transmembrane domain and a cytoplasmic tyrosine kinase domain. Binding of a specific ligand to one of the erbB receptors triggers the formation of specific receptor homo- and heterodimers, with erbB2 as the preferred signaling partner (2). Signaling from heterodimers usually presents distinct features compared to the corresponding homodimers as a way of diversifying the signal (3). It was demonstrated that the role of erbB in cell proliferation, differentiation and survival is of extreme significance $(4,5)$.

ErbB2 overexpression and amplification were observed in a variety of human epithelial tumors and were correlated with an unfavourable prognosis in patients with breast and ovarian cancer (6). Heterodimeric receptor combinations containing erbB2, particularly erbB2-erbB3, exhibit superior signal-transducing and cell-growth stimulating capabilities (7-9). The evidence indicates that erbB2 confers an autocrine growth advantage to tumor cells.

Various growth factor receptors (VEGFR; erbB1, erbB2 or erbB3) (10-12), cytokine receptors (IL-1 $\beta$ and IL-2) (13) and even ion channels (CFTR) (14) have soluble forms capable of ligand binding, frequently detected in cultured tumor cells, conditioned media and in biological fluids, including blood and urine. These soluble forms are produced by limited proteolysis of full membrane receptors (15-18) or by alternative splicing $(10,11,19)$. Their transcripts codify for proteins that retain all, a part or nothing from the transmembrane or cytoplasmic domains. Their widespread presence indicates that these soluble forms may have important physiological functions, since the relative abundance of these mRNAs usually changes with the developmental stage of morphogenesis. Given that 3T3-L1 cells differentiate from preadipocytes (fibroblasts) to adipocytes, a mechanism of this type is to be expected. The occurence of these receptor isoforms in 3T3-L1 cells may be of interest since they have not been previously described in adipocytes and their presence may explain the modulation that erbB2 and EGFR exhibit at the protein level during and after the differentiation induction phase (20). 
Previously, we studied erbB1/EGFR, erbB2, erbB3 and erbB4 as well as ligands, heregulin and EGF, in terms of expression, activation and modulation during the adipogenic process in 3T3-L1 cells $(20,21)$. In this study, the presence of full-length erbB mRNAs and, of splice or proteolytic variants were examined using RT-PCR.

\section{Materials and methods}

Cell culture. Swiss 3T3-L1 preadipocytes (fibroblasts, embryo, mouse: ATCC CCL 92.1), purchased from the Asociación Banco Argentino de Células, were routinely cultured in Dulbecco's modified Eagle's medium (DMEM) (Hyclone) with $4 \mathrm{mM}$ L-glutamine, $4.5 \mathrm{~g} / 1$ glucose, $1 \times 10^{-6} \mathrm{M}$ biotin and $0.11 \mathrm{~g} / 1$ sodium pyruvate, and supplemented with $10 \%$ fetal bovine serum (FBS) (Gen SA, Bs. As.) plus antibiotics (Gibco, Life Technologies).

RNA extraction, RT-PCR and primer sets. Total cellular RNA was isolated by the Chomczynski and Sacchi method (22). Briefly, $1 \times 10^{7}$ 3T3-L1 cells were harvested during the proliferative phase. Cell monolayers were washed twice with $\mathrm{Ca}^{2+}$ and $\mathrm{Mg}^{2+}$ free-cold phosphate buffered saline (PBS), and cells were collected with a rubber policeman in $1 \mathrm{ml} / \mathrm{dish}$ of D Solution [4 M guanidinium thiocyanate, $25 \mathrm{mM}$ sodium citrate ( $\mathrm{pH} 7$ ), 0.5\% w/v sarkosyl, $0.1 \mathrm{M} \beta$-mercaptoethanol], finishing lysis by passaging cells 5 times using a $21 \mathrm{G}$ needle. Considering a total final volume of $10 \mathrm{ml}, 1 \mathrm{ml} 2 \mathrm{M}$ sodium acetate ( $\mathrm{pH} 4), 10 \mathrm{ml}$ water-saturated phenol ( $\mathrm{pH} 5)$ and $2 \mathrm{ml}$ 49:1 chloroform/isoamyl alcohol were added, mixing thoroughly each time, with vortex agitation twice for $30 \mathrm{sec}$ with an intermediate rest time of 1 min on ice. After $15 \mathrm{~min}$ of incubation on ice, the suspension was centrifuged at $10,000 \mathrm{rpm}$ at $4^{\circ} \mathrm{C}$ for $20 \mathrm{~min}$ and the aqueous phase was transferred to a fresh tube and mixed with an equal volume of isopropyl alcohol. Samples were maintained for at least $3 \mathrm{~h}$ at $-20^{\circ} \mathrm{C}$. After another centrifugation at $10,000 \mathrm{rpm}$ at $4^{\circ} \mathrm{C}$ for 20 min, the supernatant was discarded and the RNA pellet was dissolved in $2 \mathrm{ml}$ D Solution. RNA was again precipitated with $1 \mathrm{ml}$ isopropyl alcohol and maintained at $-20^{\circ} \mathrm{C}$ for at least $3 \mathrm{~h}$. Following centrifugation at $10,000 \mathrm{rpm}$ at $4^{\circ} \mathrm{C}$ for $20 \mathrm{~min}$, the supernatant was discarded and the RNA pellet was washed with $70 \%$ ethanol, air-dried and resuspended in $100 \mu \mathrm{l}$ RNAse-free water. RNA purity and concentration were evaluated spectrophotometrically (ADN/ARN absorbance, 1.8) and visually (in $1 \%$ agarose gels, stained with ethidium bromide, presence of 2 bands corresponding to $18 \mathrm{~S}$ and 28S).

RT-PCR. The Promega Corp. System and a Mastercycler gradient thermocycler (Eppendorf, Hauppauge, NY, USA) were used to transcribe and amplify RNA. Briefly, RNA was incubated for $10 \mathrm{~min}$ at $70^{\circ} \mathrm{C}$ to destabilize secondary structures and after a brief centrifugation it was rapidly cooled on ice. cDNA was obtained through reverse transcription (RT) in the following mix reaction: $5 \mathrm{mM} \mathrm{MgCl}_{2}$, buffer $[10 \mathrm{mM}$ Tris- $\mathrm{HCl}(\mathrm{pH} 9.0), 50 \mathrm{mM} \mathrm{KCl}$ and $0.1 \%$ v/v Triton X-100], $1 \mathrm{mM}$ dNTP, $15 \mathrm{U} / \mu \mathrm{g}$ AMV reverse transcriptase, Rnasin ${ }^{\circledR}$ $1 \mathrm{U} / \mu 1$ recombinant ribonuclease inhibitor, $50 \mathrm{ng} / \mu 1 \mathrm{RNA}$ and $0.025 \mu \mathrm{g} / \mu 1$ random 'primers', with a pre-incubation step at room temperature followed by an incubation step at $42^{\circ} \mathrm{C}$ for
$60 \mathrm{~min}$. The sample was heated at $95^{\circ} \mathrm{C}$ for $5 \mathrm{~min}$ to inactivate the AMV enzyme and then maintained on ice until use.

For PCR reactions, 20 ng cDNA previously transcribed, 2-4 mM $\mathrm{MgCl}_{2}$, Buffer [10 mM Tris- $\mathrm{HCl}$ (pH 9.0), $50 \mathrm{mM}$ $\mathrm{KCl}$ and $0.1 \% \mathrm{v} / \mathrm{v}$ Triton X-100], $200 \mu \mathrm{M}$ dNTP, $15 \mathrm{U} / \mu \mathrm{g}$ Taq DNA polymerase and $0.5 \mu \mathrm{M}\left(5^{\prime}\right.$ and $\left.3^{\prime}\right)$ specific primers were used.

Samples were subjected to a single pre-denaturing cycle at $94^{\circ} \mathrm{C}$ for $5 \mathrm{~min}$, followed by 30 cycles, each with a denaturing step at $94^{\circ} \mathrm{C}$ for $30 \mathrm{sec}$, annealing at a specific temperature for each set of primers for $1 \mathrm{~min}$ and elongation at $72^{\circ} \mathrm{C}$ for $2 \mathrm{~min}$, ending with a final elongation at $72^{\circ} \mathrm{C}$ for $7 \mathrm{~min}$ and polymerase inactivation at $4^{\circ} \mathrm{C}$.

Primers. All sets of primers, with the exception of those for EGFR/erbB1 (Genosys, Canada), were acquired from Tecnolab SA, Argentina (for Operon, a Qiagen company) and desalted in a 50-nM scale (Table I).

After amplification, specific fragments were separated and visualized in $1 \%$ agarose (Seakem ME) gels in buffer TBE [0.9 M Tris, 0.9 M boric acid and $20 \mathrm{mM}$ EDTA (pH 7.8)] stained with ethidium bromide, at $70 \mathrm{~V}$ for $30 \mathrm{~min}$.

Restriction enzyme analysis. PCR product specificity was analyzed by endonuclesase restriction, with enzymes that cleave DNA inside specific sequences, generally palindromes. Basically, we searched for enzymes restriction sites in the amplified segment sequence and then, which one of them cut only once and finally, between these ones, which ones produce segments of a proper size to be observed in an agarose gel. Enzymatic digestion was performed using the reaction mixture: $5 \mu \mathrm{l}$ PCR product, $0.5 \mu \mathrm{l}$ endonuclease, $1 \mu \mathrm{l}$ buffer and $3.5 \mu \mathrm{l}$ water. The reaction was incubated at $37^{\circ} \mathrm{C}$ for $3 \mathrm{~h}$ and stopped with loading buffer $[0.03 \%$ bromophenol blue, $0.03 \%$ cylene cyanol, $0.4 \%$ orange G, 15\% Ficoll 400, $10 \mathrm{mM}$ Tris- $\mathrm{HCl}$ (pH 7.5) and $50 \mathrm{mM}$ EDTA]. The PCR products digested in this manner were analyzed together with the undigested fragments in agarose gels to visualize the reaction and check for cleavage efficiency according to the expected length (pb).

RsaI. Pseudomonas sphaeroides (Biolabs). 5'...GTvAC...3', 3'...CA^TG...5'; Eco RI 5'...G CTTAA $\triangle$ G...5'.

\section{Results}

erbB2 mRNA expression in 3T3-L1 cells. ErbB2 expression in a variety of human cancers, such as breast, ovary and lung cancer, has been extensively documented in terms of overexpression and amplification. However, erbB2 expression or the presence of ErbB in general have not been frequently described in fibroblasts, with the exception of decidua cells $(23,24)$, mammary gland fibroblasts (25) and the Rat-1 cell line (26). Therefore, erbB expression was evaluated in the 3T3-L1 model of adipogenic differentiation.

Of note is that when these experiments were first started, the complete murine erbB2 sequence was unknown (at present, the complete v-erbB2 murine sequence BC046811 is known to present an $83-87 \%$ homology with the human c-erbB2). Only a partial sequence was available (2,083 bp) 
Table I. List of PCR primers used.

\begin{tabular}{|c|c|c|}
\hline Receptor & Genbank accession no. & Primer Sequence ( $5^{\prime}$ to $3^{\prime}$ ) \\
\hline erbB2 & $\begin{array}{l}\text { Human }(31997) \text { X03363 } \\
3,416 \rightarrow 3,437 \\
\text { Mouse }(200711980) \text { AK031099 } \\
1,036 \rightarrow 1,057 \\
\text { Human } 3,723 \leftarrow 3,744 \\
\text { Mouse } 1,343 \leftarrow 1,364\end{array}$ & F: CT GGC TCC GAT GT(A/G) TTT 3GAT GG \\
\hline HER2-ECD & & $\begin{array}{l}\text { F: AGG GAG TAT GTG A(A/G)(G/T) G(C/G)C } \\
1,828 \rightarrow 1,845 \\
\text { R: CCT GAA AGA AAG TCC TCC }\end{array}$ \\
\hline Herstatin & (10181232) AF177761 & $\begin{array}{l}\text { F: TG AGC ACC ATG GAG CTG GC } \\
\text { 167 } \rightarrow 185 \\
\text { R: TC CGG CA(A/G) AAA TGC CAG GCT CC } \\
1,289 \leftarrow 1,310\end{array}$ \\
\hline EGFR & Mouse (488830) X78987 & $\begin{array}{l}\text { F: CC AAA TGT GAT CCA AGC TGT CC } \\
622 \rightarrow 643 \\
\text { R: TCC GAG GAG CAT AAA GGA TTG } \\
1,577 \leftarrow 1,597\end{array}$ \\
\hline erbB3 & Mouse (25071684) XM_125954.4 & $\begin{array}{l}\text { F: CTG GGC GTG TCT ACA TAA GTG C } \\
\text { 11 } \rightarrow 32 \\
\text { R: A TGG CAG GAG AAG CAA TGA GCC } \\
297 \leftarrow 318\end{array}$ \\
\hline erbB4 & $\begin{array}{l}\text { Rat (4176734) AF041838 } \\
\text { Mouse (23622469) XM_136679 }\end{array}$ & $\begin{array}{l}\text { F: CAT CTA CAC ATC CAG AAC A } \\
3,133 \rightarrow 3,150 \\
\text { R: AAA CAT CTC AGC CGT TGC A } \\
3,321 \leftarrow 3,339\end{array}$ \\
\hline
\end{tabular}
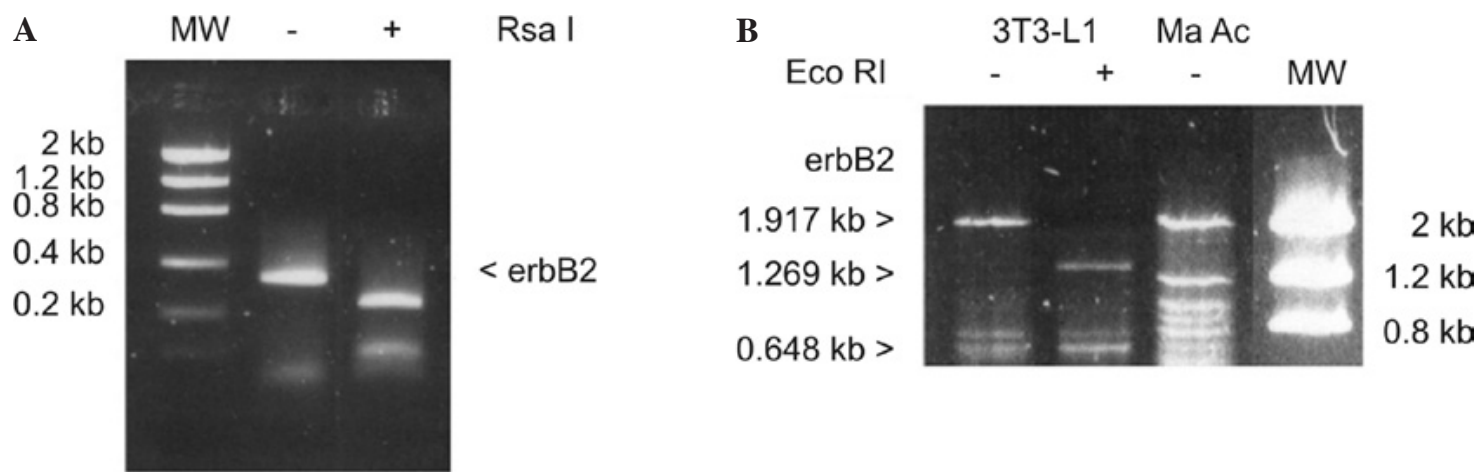

Figure 1. Wild-type erbB2 expression in 3T3-L1 cells. (A) Total RNA was extracted from 3T3-L1 proliferating cells. After obtaining cDNA by reverse transcription, erbB2 was amplified with specific primers through PCR. RsaI enzymatic digestion of the complete segment (328 bp) yielded two fragments of the expected size. (B) Amplification with a human forward primer and a murine reverse primer of a larger segment (1,917 bp) and EcoRI-specific cleavage confirmed fragment identity as erbB2. PCR products were analyzed in $1 \%$ agarose gels plus ethidium bromide in TBE buffer. Specificity of PCR products was analyzed by endonuclease cleavage. Fragments digested in this manner were run together with complete fragments to verify cleavage efficiency according to expected and obtained sizes in bp. Molecular weight markers (MW) Low DNA Mass Ladder.

corresponding to the $3^{\prime}$ end of human c-erbB2 $(4,473 \mathrm{bp}$; $87 \%$ homology). The primers were designed, based on this sequence, to detect erbB2 mRNA expression in 3T3-L1 cells through RT-PCR. This erbB2 mRNA portion has the lowest homology with EGFR $(<20 \%)$. The primers included wobble $(\mathrm{X} / \mathrm{Y})$ positions to increase possibilities of amplifying the erbB2 sequence in mouse. This set of primers provided an RT-PCR product of 300 bp (Fig. 1A), which was confirmed as erbB2 by Rsa cleavage (328 bp $=237+91 \mathrm{bp})$.
Additionally, we amplified a larger segment using this forward primer designed against the human sequence (10), whereas the primer that had previously been designed against the mouse sequence was used as the reverse primer. This combination of primers yielded a segment of $\sim 1,900$ bp (Fig. 1B), confirmed as erbB2 by EcoRI cleavage $(1,917$ bp $=1,269+648$ bp).

To the best of our knowledge, this is the first observation of erbB2 mRNA expression in the 3T3-L1 cell line in the literature. 


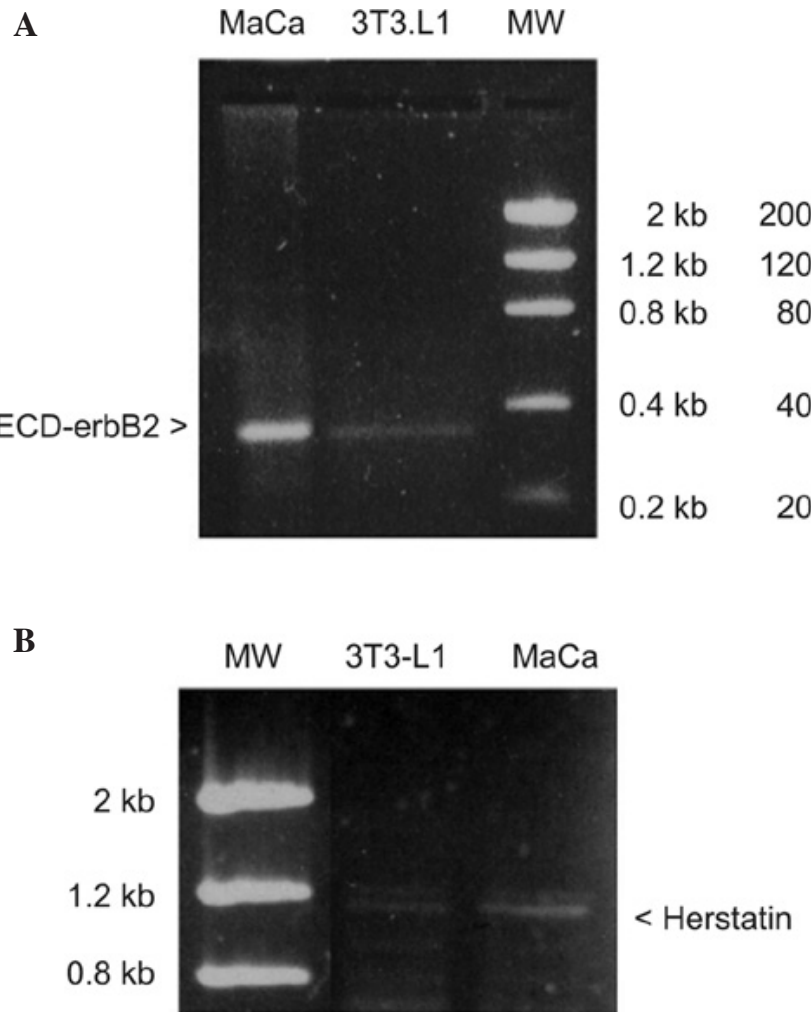

Figure 2. erbB2 splicing variant expression in 3T3-L1 cells. (A) Using oligonucleotides designed to amplify a human truncated version of erbB2 (lacking cytoplasmic domain), HER2-ECD expression in 3T3-L1 cells was obtained (expected product size, $290 \mathrm{bp}$ ). It is evident that its expression is lower than that of a murine breast carcinoma (CaMa). It was used as the molecular weight marker (MW) Low DNA Mass Ladder. Subsequently, an evaluation of the mass bands was performed. While the full PCR reaction volume was loaded in two wells for 3T3-L1 cells, only half was loaded for CaMa (approximate ratio 3T3-L1/CaMa, 1/4). (B) Herstatin, another erbB2 soluble truncated variant, was amplified from the 3T3-L1 cell cDNA. Breast cancer cells (CaMa) as well as 3T3-L1 cells exhibit a very low fragment expression (1,143 bp).

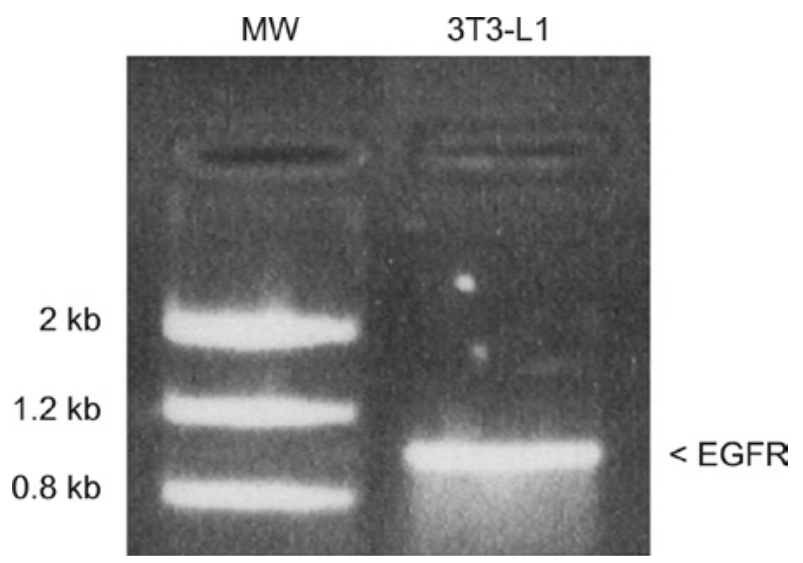

Figure 3. EGFR expression in 3T3-L1 cells. Total RNA from 3T3-L1 cells underwent RT-PCR for EGFR mRNA. The product has the expected size (975 bp). Molecular weight markers (MW) Low DNA Mass Ladder.

\section{erbB2 splicing variants in 3T3-L1 cells}

HER2-ECD expression in 3T3-L1 cells. We evaluated the possibility that $3 \mathrm{~T} 3-\mathrm{L} 1$ cells express an erbB2 variant that provides a truncated protein of $100 \mathrm{kDa}$, the human erbB2-extracellular domain (HER2-ECD), which has an antiproliferative activity in tumor cells with a tendency to disappear in more advanced or aggressive tumor phenotypes. This splicing variant is derived from a $2.3 \mathrm{~kb}$-mRNA, almost half the wild-type length, which retains the four extracellular subdomains, but loses the transmembrane and the cytoplasmic domains (from the 633 aa it embraces, the last 25 from the $3^{\prime}$ end differ from the wild-type).

Another set of primers (Table I) (10) was used to identify this alternative splice variant. As shown in Fig. 2A a specific fragment was positively amplified with the expected size for HER2-ECD in 3T3-L1 cells, by the lack of any other bands. HER2-ECD expression was low in comparison with that shown by breast carcinoma.

Herstatin expression in 3T3-LI cells. Herstatin (AF177761) is a $68-\mathrm{kDa}$ protein described as an erbB2 autoinhibitor, which, upon binding to the receptor itself, interferes with dimer formation and reduces receptor tyrosine phosphorylation (19). It is produced by an alternative truncated mRNA whose protein contains the first 340 aa of the erbB2 protein (ECD subdomains I and II) fused to a unique stretch of 79 aa that arises from the insertion of an intronic sequence.

Using the primers previously described (Materials and methods and Table I), we obtained an RT-PCR product of the expected length (1,143 bp) positively amplified in 3T3-L1 cells as in epithelial cells from murine breast cancer (Fig. 2B), although it appears evident that the expression of each one is relatively low.

As for HER2-ECD, the meaning or function of a low herstatin expression in 3T3-L1 cells, as in any other normal cells, would require more attention. It is possible that the expression of these erbB2 variants as alternative mechanisms to control cell proliferation and/or erbB2 activity are not required under physiological circumstances, although they are ready to be activated in case of need.

EGFR/erbB1 expression in 3T3-L1 cells. The proliferative dependence of 3T3-L1 cells on EGF presence in the culture medium was described at the beginning of this model characterization (27), whereas its receptor expression was described at the protein level (28). EGFR expression in adipocytes was demonstrated in in vivo studies (29) as well as in 3T3-L1 cell line cultures $(28,30,31)$. In this study, EGFR expression was confirmed by RT-PCR in our 3T3-L1 cell system using specific primers designed in our lab from the complete murine sequence (gi: 488830, X78987) (Fig. 3).

erbB3 expression in 3T3-L1 cells. A set of primers matching the $5^{\prime}$ end of this cDNA was designed from the 4,524 bp erbB3 sequence found in the NCBI database (gi: 25071684, XM_125954.4). These primers amplified several fragments by RT-PCR in 3T3-L1 cells, and one of these fragments had the expected size (308 bp) for erbB3.cDNA samples from a murine breast cancer and rat normal mammary acines were used as positive controls (Fig. 4A). The identity of erbB3 was confirmed by RsaI cleavage (Fig. 4B), which yielded two fragments of 104 and $204 \mathrm{bp}$. This is the first demonstration of erbB3 expression in preadipocytes in vivo as well as in vitro.

erbB4 expression in 3T3-L1 cells. Since the murine erbB4 sequence was incomplete (gi: 23622469, XM_136679), a combination of primers designed against the rat sequence were used (32) (gi: 4176734, AF041838). Homology of 95\% was observed between the rat 4,060 bp and the mouse 1,284 bp. 
A
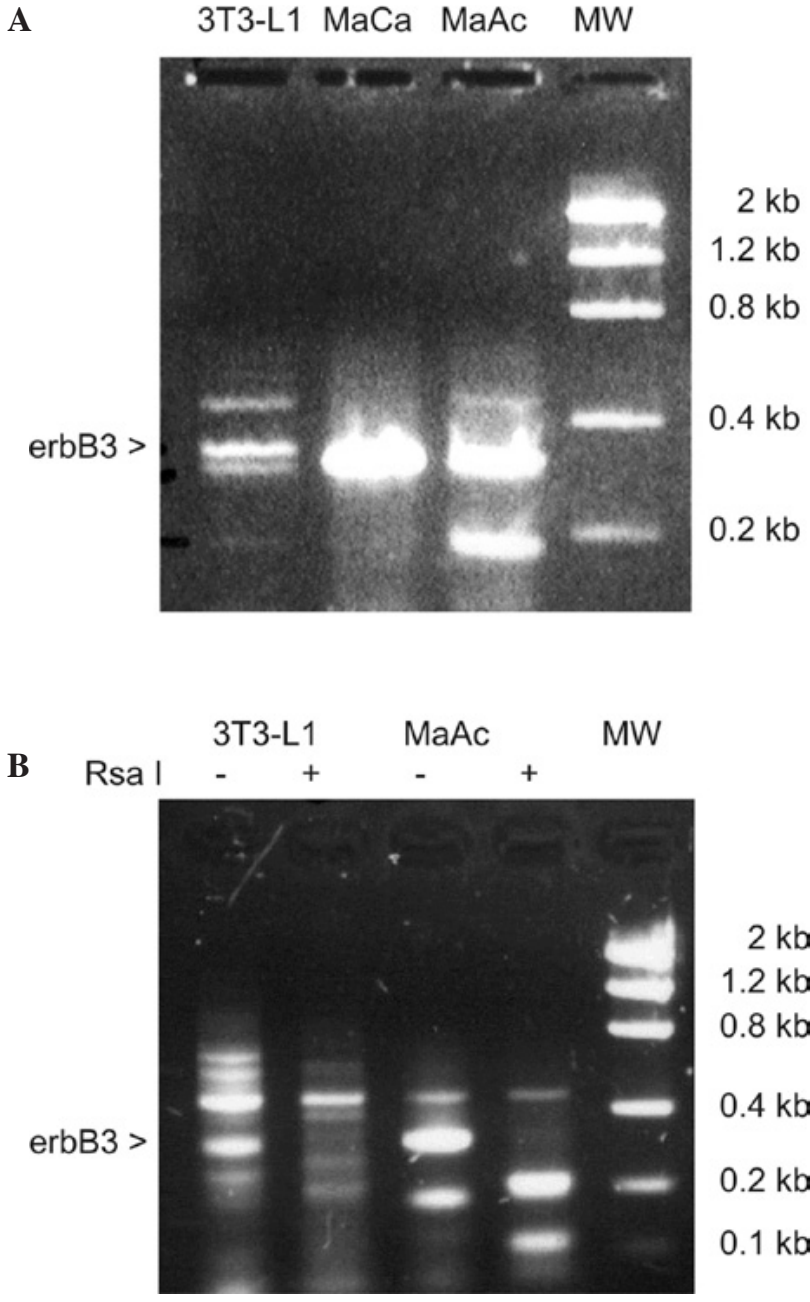

Figure 4. erbB3 expression in 3T3-L1 cells. (A) erbB3 was amplified by RT-PCR in 3T3-L1 cells, using murine breast carcinoma cells (CaMa) and normal rat mammary acines (AcMa) as positive controls. (B) Since amplification produced several fragments besides the expected one (308 bp), its specificity was examined by RsaI cleavage $(104+204$ bp). Positive control: normal rat mammary acines (AcMa).

Homology was absolute (100\%) between the primer binding regions. On the other hand, inside the region to be amplified there are only seven mismatches and none in the binding sites of the primers. Although we were able to amplify a specific fragment of the expected size (206 bp) in rat mammary acines by RT-PCR due to the satisfactory RsaI digestion $(111+95 \mathrm{bp})$, none of the 3T3-L1 bands were erbB4 (Fig. 5).

\section{Discussion}

Since our concern was to evaluate the expression of not only the wild-type but also other mRNA variants of erbB2 in 3T3-L1 cells, we designed a set of primers and adapted and modified other primer sets obtained from the literature to achieve this target, based on a mouse sequence of only 2,083 bp with an $87 \%$ homology with its human counterpart (Fig. 1A). Primers recognized identical cDNA regions in both species with one base exception, allowing us to prepare wobble oligomers, which carry the murine or human base in that position in equal parts. In this manner, segment amplification was ensured despite this minor discrepancy. The amplified
A MW 3T3-L1 MaCa MaAc
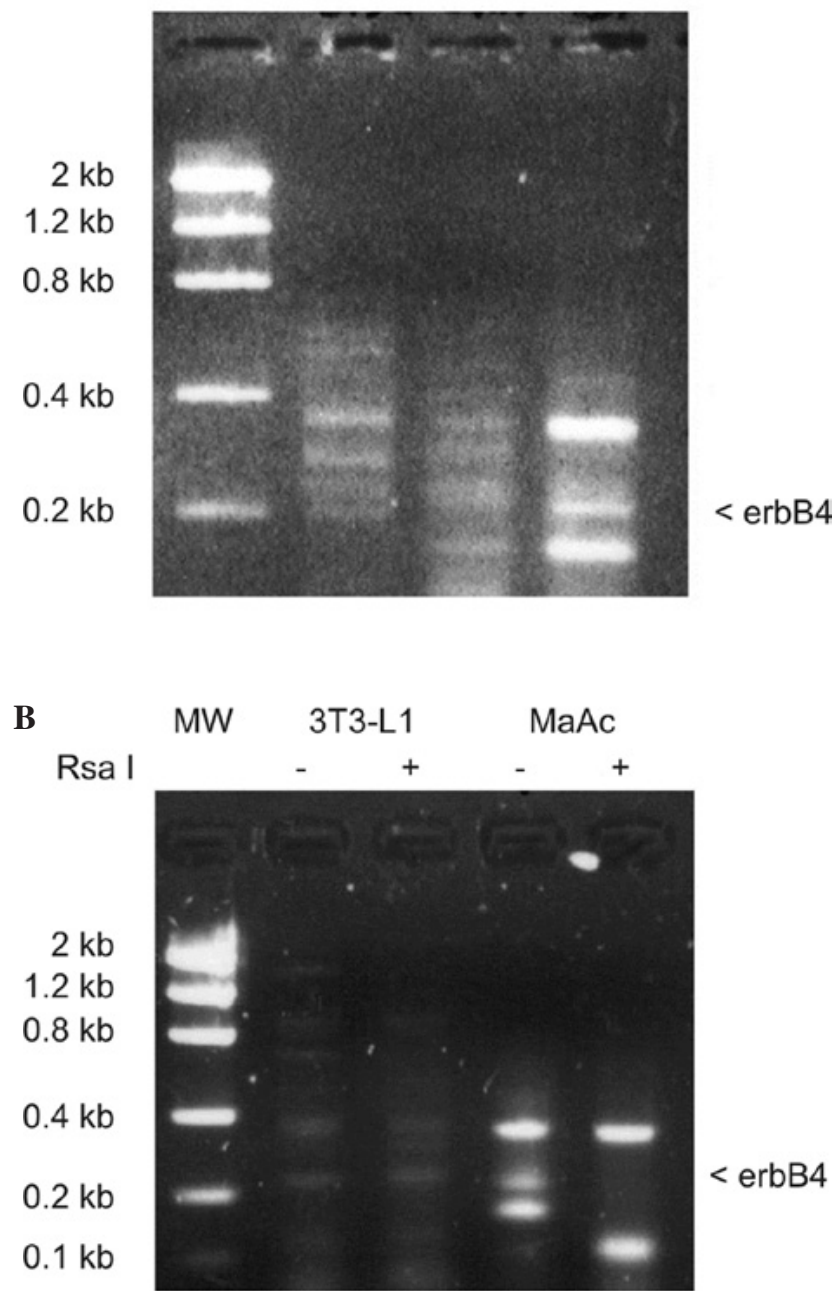

Figure 5. erbB4 expression in 3T3-L1 cells. (A) From total cDNA of 3T3-L1 cells, we attempted to amplify erbB4, using murine breast carcinoma cells $(\mathrm{CaMa})$ and normal rat mammary acines (AcMa) as positive controls. The three sources produced several fragments. (B) 3T3-L1 band specificity was studied by RsaI cleavage, but none were revealed to be erbB4, since the expected size $(206 \mathrm{bp}=111+95 \mathrm{bp})$ was only exhibited by rat acines.

sequence was shown to match erbB2. Additionally, we were able to amplify a larger fragment using a $5^{\prime}$ human (10) and a $3^{\prime}$ murine primer that were previously used (Fig. 1B). In each case, enzymatic digestion allowed us to obtain a positive match with erbB2 mRNA, since cleavage sites remained intact in the two species. This result shows the high degree of homology that murine and human erbB2 share.

HER2-ECD has been described as one of these splicing variants (11). HER2-ECD is expressed in numerous tumor cell lines that also express erbB2/HER2, and its relative abundance is variable. In gastric cancer cells (MKN7) it is higher than, in decreasing order, ovarian (SK-OV-3) and breast cancer cells (BT-474 y SK-BR-3). HER2-ECD has also been observed in the sera of HER2-carrying tumor patients (33), in ganglia micrometastasis, in bone marrow (34) and in conditioned media from cell lines mostly produced by limited proteolysis as opposed to alternative splicing. However, HER2-ECD remained in the cytoplasm in the latter case. HER2-ECD function in tumor cells is not currently well understood. The role of HER2-ECD mRNA loss in advanced 
gastric tumors indicates a potential role for erbB2 truncated forms in controlling tumor proliferation in humans. It is also likely that HER2-ECD function depends on the tumoral type under study, since high levels in the sera of oncologic patients inversely correlate with chemotherapy results (33). Since this variant is devoid of the kinase domain and is therefore unable to transduce intracellular signals, some authors have proposed that it may aggregate with complete receptors of the erbB family to modulate their activity (34), in a similar fashion to the inactivation that follows normal and truncated EGFR interaction $(35,36)$. Although it was possible to amplify HER2-ECD in 3T3-L1 cells with specific primers (Fig. 2A), its expression was found to be lower than that of a breast carcinoma. Despite this, it is possible that future studies may demonstrate the existence of erbB2 variants in mice and their possible function in adipogenesis, whether similar or not to their human counterparts, since no previous studies are currently available on this subject.

Herstatin, another erbB2 splicing variant, is produced after a truncated mRNA $(2.6 \mathrm{~kb})$ that codifies only for the first two extracellular subdomains (19). Herstatin is present in human fetal kidney and liver and in the non-tumorigenic cell lines IOSEVAN (epithelial ovarian cells) and HBL-100 (mammary cells), while its expression is lower in cells where erbB2 is amplified, such as BT474 or SKOV-3 (19). In this study, it was possible to obtain the expected size fragment in 3T3-L1 cells using primers described by Doherty et al (19), although its expression was found to be extremely low, not only in these cells, but also in breast carcinoma ones (Fig. 2B). Therefore, more studies are required to assess the expression of erbB2 variants in 3T3-L1 cells and any connection that may exist with adipogenic differentiation.

ErbB3 is another member of this family of receptors, occasionally referred to as 'the dumb', as well as erbB2, 'the deaf'. This is due to the fact that erbB3 has a deficient kinase that prevents it from transducing an intracellular signal, and because erbB2 has no known ligand to date; hence, it is unable to 'listen' (37). For these reasons, the receptors are compelled to dimerize with a different dimerization partner, unless in case of a receptor overexpression. The erbB2-erbB3 heterodimer is able to transduce one of the more potent mitogenic signals in this family and to cause neoplastic transformation (38). Therefore, it was crucial for our differentiation model to test erbB3 mRNA existence in 3T3-L1 cells. erbB3 also has different isoforms, of which p85-serbB3 (soluble) is capable of inhibiting heregulinmediated erbB2, erbB3 and erbB4 activation $(39,40)$. However, in this study, only the wild-type receptor was investigated [erbB3 expression in 3T3-L1 cells at the protein level, previously published (20)]. Based on the erbB3 murine sequence, we designed a pair of primers corresponding to mRNA 5' end that amplified a fragment of the expected size $(308 \mathrm{pb})$ plus two more fragments of variable size (Fig. 4A). A murine breast carcinoma and normal rat mammary acines were used as a positive control, since they present high erbB3 expression $(25,41)$. The fragment was shown to be specific by restriction analysis (Fig. 4B). The observation of erbB3 expression in 3T3-L1 or adipocytic cells for the first time in the literature indicates a possibility for erbB3 function inside the adipogenic process.

ErbB4 is the last member of this family to be described. It mediates neuregulins and other EGF-related growth factor responses. It has a fundamental role in the regulation of cardiac, neural and mammary development and, as with erbB2, it is also related to neoplastic transformation and cardiac disorders. Chemotaxis and cellular survival are regulated by the expression of erbB4 isoforms that differ in their ability to couple PI3-K signaling (42). Four isoforms have been identified as structurally and functionally different from erbB4, which are sensitive or resistant to the proteolytic cleavage that releases a soluble extracellular domain and which are able or unable to activate MAPK or PI3-K/Akt pathways, explaining the different cellular outputs transduced through each of them (43).

erbB4 expression has not previously been investigated before in this model of adipogenic differentiation. The murine sequence was not complete, resulting in rat sequence-based designed primers being used (32). Homology of 95\% was observed between the 4,060 bp rat sequence and the 1,084 bp mouse sequence. Homology was absolute $(100 \%)$ in the binding region of the primers. erbB4 was positively amplified in rat mammary acines, but none of the bands were revealed to be erbB4 in 3T3-L1 cells (Fig. 5). We have already discussed the presence of receptor isoforms at the protein level in a previous study (20).

Supporting these results, it is notable that the full presence of all members of the erbB family would be redundant in a single cell type, particularly if normal. Usually, a cell expresses one or two erbBs, and no more than three. For example, NIH-3T3 cells lack endogenous detectable levels of EGFR, erbB3 and erbB4 and exhibit only extremely low levels of erbB2 (3), while only EGFR and erbB2 are present in Rat-1 fibroblasts (26). Therefore, the mRNA expression of erbB2, erbB1/EGFR and erbB3 was confirmed in 3T3-L1 cells in this study.

Expression of erbB2 at the protein level in 3T3-L1 cells (20) and its involvement in the proliferation/differentiation processes of these cells were previously observed (21). The present study completes our understanding of the expression, modulation and activation of the erbB receptors in the 3T3-L1 cell line and poses new questions regarding possible roles for erbB soluble forms in this adipogenic model.

\section{Acknowledgements}

The authors thank Mr. M. Fourcade for the assistance in the preparation of the figures. This study was partially supported by a grant from ANPCyT (PICT 05-00000-00206) and UBACYT (X031).

\section{References}

1. Brennan PJ, Kumogai T, Berezov A, Murali R and Greene MI: HER2/Neu: mechanisms of dimerization/oligomerization. Oncogene 19: 6093-6101, 2000.

2. Graus-Porta D, Beerli RR, Daly JM and Hynes NE: ErbB-2, the preferred heterodimerization partner of all erbB receptors, is a mediator of lateral signaling. EMBO J 16: 1647-1655, 1997.

3. Olayioye MA, Graus-Porta D, Beerli RR, Rohrer J, Gay B and Hynes NE: ErbB-1 and ErbB-2 acquire distinct signaling properties dependent upon their dimerization partner. Mol Cell Biol 18: 5042-5051, 1998.

4. Olayioye MA, Neve R, Lane HA and Hynes NE: The ErbB signaling network: receptor heterodimerization in development and cancer. EMBO J 19: 3159-3167, 2000.

5. Olayioye MA: Update on HER-2 as a target for cancer therapy. Intracellular signaling pathways of ErbB2/HER-2 and family members. Breast Cancer Res 2001: 385-389, 2002. 
6. Slamon DJ, Clark G, Wong S, Levin W, Ullrich A and McGuire W: Human breast cancer: correlation of relapse and survival with amplification of the HER2/neu oncogene. Science 235: 177-182, 1986

7. Graus-Porta D, Beerli RR and Hynes NE: Single-chain antibody-mediated intracellular retention of erbB2 impairs neu differentiation factor and epidermal growth factor signaling. Mol Cell Biol 15: 1182-1191, 1995.

8. Karunagaran D, Tzahar E, Beerli RR, Chen XH, Graus-Porta D, Seger R, Hynes NE and Yarden Y: ErbB2 is a common auxiliary subunit of NDF and EGF receptors: implications for breast cancer. EMBO J 15: 254-264, 1996.

9. Pinkas-Kramarski R, Soussan L, Waterman H, Levkowitz G, Alroy I, Klapper L, Lavi S, Seger R, Ratzkin B, Sela M and Yarden Y: Diversification of neu differentiation factor and epidermal growth factor signaling by combinatorial receptor interactions. EMBO J 15: 2452-2467, 1996.

10. Aigner A, Juhl H, Malerczyk C, Tkybusch A, Benz CC and Czubayko F: Expression of a truncated 100 kDa HER2 splice variant acts as an endogenous inhibitor of tumour cell proliferation. Oncogene 20: 2101-2111, 2001.

11. Scott G, Robles R, Park JW, Montgomery P, Daniel J, Holmes WE, Lee J, Keller G, Li W, Fendly BM, Wood W, Shepard M and Benz CC: A truncated intracellular HER2/neu receptor produced by alternative RNA processing affects growth of human carcinoma cells. Mol Cell Biol 13: 2247-2257, 1993.

12. Katoh M, Yazaki Y, Sugimura T and Terada M: c-erbB3 gene encodes secreted as well as transmembrane receptor tyrosine kinase. Biochem Biophys Res Commun 192: 1189-1197, 1993.

13. McMahan C, Slack J, Mosley B, et al: A novel IL-1 receptor, cloned from B cells by mammalian expression, is expressed in many cell types. EMBO J 10: 2821-2832, 1991.

14. Huber S, Braun G, Burger-Kentischer A, Reinhart B, Luckow B and Horster M: CFTR mRNA and its truncated splice variant (TRN-CFTR) are differentially expressed during collecting duct ontogeny. FEBS Lett 423: 362-366, 1998.

15. Zabrecky J, Lam T, McKenzie S and Carney W: The extracellular domain of $\mathrm{p} 185 /$ neu is released from the surface of human breast carcinoma cells, SK-BR-3. J Biol Chem 266: 1716-1720, 1991.

16. Lin Y and Clinton GM: A soluble protein related to the HER2-proto-oncogene product is released from human breast carcinoma cells. Oncogene 6: 639-643, 1991.

17. Pupa S, Menard S, Morelli D, Pozzi B, De Palo G and Colnaghi M: The extracellular domain of the c-erbB-2 oncoprotein is released from tumor cells by proteolytic cleavage. Oncogene 8: 2917-2923, 1993.

18. Codony-Servat J, Albanell J, Lopez-Talavera JC, Arribas J and Baselga J: Cleavage of the HER2 ectodomain is a pervanadateactivable process that is inhibited by the tissue inhibitor of metalloproteases-1 in breast cancer cells. Cancer Res 59: 1196-1201, 1999

19. Doherty JK, Bond C, Jardim A, Adelman J and Clinton GM: The HER-2/neu receptor tyrosine kinase gene encodes a secreted autoinhibitor. Proc Natl Acad Sci USA 96: 10869-10874, 1999.

20. Pagano E and Calvo JC: ErbB2 and EGFR are downmodulated during the differentiation of 3T3-L1 preadipocytes. J Cell Biochem 90: 561-572, 2003.

21. Pagano E, Coso O and Calvo JC: Down-modulation of erbB2 activity is necessary but not enough in the differentiation of 3T3-L1 preadipocytes. J Cell Biochem 104: 274-285, 2008.

22. Chomczynski P and Sacchi N: Single step method of RNA isolation by acid guanidinium thiocyanate-phenol-chloroform extraction. Anal Biochem 162: 156-159, 1987.

23. Lim H, Dey SK and Das SK: Differential expression of the erbB2 gene in the periimplantation mouse uterus: potential mediator of signaling by epidermal growth factor-like growth factors. Endocrinology 138: 1328-1337, 1997.

24. Press MF, Cordon-Cardo C and Slamon DJ: Expression of the HER-2/neu proto-oncogene in normal human adult and fetal tissues. Oncogene 5: 953-962, 1990.

25. Schroeder JA and Lee DC: Dynamic expression and activation of ERBB receptors in the developing mouse mammary gland. Cell Growth Differ 9: 451-464, 1998.

26. Stern DF and Kamps MP: EGF-stimulated tyrosine phosphorylation of p185neu: a potential model for receptor interactions. EMBO J 7: 995-1001, 1998
27. Schmidt W, Pöll-Jordan G and Löffler G: Adipose conversion of 3T3-L1 cells in a serum-free culture system depends on epidermal growth factor, insulin-like growth factor-1, corticosterone, and cyclic AMP. J Biol Chem 265: 15489-15495, 1990.

28. Reed BC, Kaufmann SH, Mackall JC, Student AK and Lane MD: Alterations in insulin binding accompanying differentiation of 3T3-L1 preadipocytes. Proc Natl Acad Sci USA 74: 4876-4880, 1977 .

29. Serrero G and Mills D: Physiologic role of EGF on adipose tissue development in vivo. Proc Natl Acad Sci USA 88: 3912-3916, 1991

30. Adachi H, Kurachi H, Homma H, Adachi K, Takashi I, Morishige $\mathrm{K}$, Matsuzawa $\mathrm{Y}$ and Miyake A: Epidermal growth factor promotes adipogenesis of 3T3-L1 cell in vitro. Endocrinology 135: 1824-1830, 1994.

31. Hardy R, Gupta K, MacDonald J, Williford J and Wells A: Epidermal growth factor (EGF) receptor carboxy-terminal domains are required for EGF-induced glucose transport in transgenic 3T3-L1 adipocytes. Endocrinology 136: 431-439, 1995 .

32. Sundaresan S, Roberts PE, King KL, Sliwkowski MX and Mather JP: Biological response to ErbB ligands in nontransformed cell lines correlates with a specific pattern of receptor expression. Endocrinology 139: 4756-4764, 1998

33. Colomer R, Montero S, Lluch A, Ojeda B, Barnadas A, Casado A, Massuti B, Cortes-Funes H and Lloveras B: Circulating HER2 extracellular domain and resistance to chemotherapy in advanced breast cancer. Clin Cancer Res 6: 2356-2362, 2000.

34. Gebhardt F, Zänker K and Brandt B: Differential expression of alternatively spliced c-erbB-2 mRNA in primary tumors, lymph node metastases, and bone marrow micrometastases from breast cancer patients. Biochem Biophys Res Commun 247: 319-323, 1998.

35. O'Rourke D, Nute E, Davis J, Wu C, Lee A, Murali R, Zhang H, Qian X, Kao C and Greene MI: Inhibition of a naturally occurring EGFR oncoprotein by the p185neu ectodomain: implications for subdomain contributions to receptor assembly. Oncogene 16: 1197-1202, 1998.

36. Basu A, Raghunath R, Bishayee S and Das M: Inhibition of tyrosine kinase activity of the epidermal growth factor (EGF) receptor by a truncated receptor form that binds to EGF: role for interreceptor interaction in kinase regulation. Mol Cell Biol 9: 671-677, 1989.

37. Citri A, Kochupurakkal BS and Yarden Y: The deaf and the dumb: the biology of ErbB-2 and ErbB-3. Exp Cell Res 284: 54-65, 2003.

38. Alimandi M, Romano A, Curia MC, Muraro R, Fedi P, Aaronson SA, Di Fiore PP and Kraus MH: Cooperative signaling of ErbB3 and ErbB2 in neoplastic transformation and human mammary carcinomas. Oncogene 10: 1813-1821, 1995.

39. Lee $\mathrm{H}$ and Maihle $\mathrm{N}$ : Isolation and characterization of four alternate c-erbB3 transcripts expressed in ovarian carcinomaderived cell lines and normal human tissues. Oncogene 16: 3243-3252, 1998.

40. Lee H, Akita RW, Sliwkowski MX and Maihle NJ: A naturally occurring secreted human ErbB3 receptor isoform inhibits heregulin-stimulated activation of ErbB2, ErbB3, and ErbB4. Cancer Res 61: 4467-4473, 2001

41. Darcy KM, Zangani D, Wohlhueter AL, Huang RY, Vaughan MM, Russell JA and Ip MM: Changes in erbB2 (her-2/ neu), erbB3, and erbB4 during growth, differentiation, and apoptosis of normal rat mammary epithelial cells. J Histochem Cytochem 48: 63-80, 2000.

42. Kainulainen V, Sundvall M, Maatta JA, Santiestevan E, Klagsbrun M and Elenius K: A natural ErbB4 isoform that does not activate phosphoinositide 3-kinase mediates proliferation but not survival or chemotaxis. J Biol Chem 275: 8641-8649, 2000.

43. Junttila TT, Sundvall M, Maatta JA and Elenius K: Erbb4 and its isoforms: selective regulation of growth factor responses by naturally occurring receptor variants. Trends Cardiovasc Med 10: 304-310, 2000. 